\title{
CYANIDE TOXICITY FOLLOWING NITROPRUSSIDE INDUCED HYPOTENSION
}

\author{
David Aitken, David West, Frances Smith, Wojciech Poznanski, John Cowan, \\ Jeffrey Hurtig, Eric Peterson, and Brien Benoit
}

SODIUM NITROPRUSSIDE was introduced for the elective induction of hypotension during general anaesthesia because of its apparent pharmacological efficacy. ${ }^{1}$ Increased experience with this drug has led to the realization that its toxic potential is greater than previously believed. Several recently reported deaths following use of sodium nitroprusside have been attributed to the accumulation of the nitroprusside metabolite, cyanide. ${ }^{2,3}$ This has resulted in a series of revisions in the recommended dosage of sodium nitroprusside. Based on clinical experience and theoretical considerations, Davies, et al..$^{3}$ recommended that $3.5 \mathrm{mg} / \mathrm{kg}$ is the maximum dose of sodium nitroprusside that can be administered safely. Posner, et al., ${ }^{4}$ in reporting their studies of nitroprusside-induced cyanide poisoning in baboons, further recommended that the sodium nitroprusside infusion rate be limited to $10 \mu \mathrm{g} / \mathrm{kg} / \mathrm{min}$ and that the maximum dose not exceed $3 \mathrm{mg} / \mathrm{kg}$. Most recently, Vesey, et al..$^{5}$ recommended that the total dose of sodium nitroprusside should not exceed $1.5 \mathrm{mg} / \mathrm{kg}$ during short-term infusions.

In this paper the extent of cyanide accumulation and toxicity in patients receiving sodium nitroprusside infusions during intracranial surgery is reported. The doses of sodium nitroprusside employed in these studies fall within the range most recently recommended, that is, less than $1.5 \mathrm{mg} / \mathrm{kg}$.

\section{Patients And Methods}

Eight female and five male patients (aged 13-66) undergoing surgery for repair of an intracranial aneurysm, were studied. Sodium nitroprusside was infused during the operation to produce hypotension as required by the surgeon. The infusion times and doses are listed in Table I. Five patients undergoing craniotomy without elective induction of hypotension were studied as a control group.

Morphine and hyoscine were administered as premedication. All patients were operated on in a horizontal position. Anaesthesia was induced by thiopentone with tracheal intubation under pancuronium and was maintained using 65 per cent nitrous oxide in oxygen and morphine with intermittent pancuronium. A halothane

David Aitken, Ph.D., David West, M.B., Frances Smith, M.D., Ph.D., Wojciech Poznanski, M.D., John Cowan, M.B., Jeffrey Hurtig, M.D., Eric Peterson, M.D., Brien Benoit, M.D. The Department of Anaesthesia and the Divisions of Biochemistry and Neurosurgery, Ottawa Civic Hospital, Ottawa, Ontario, Canada.

Address reprint requests to Dr. Frances Smith, Division of Biochemistry, Ottawa Civic Hospital, Ottawa, Ontario, Canada. KIY 4E9

Presented at the Annual Meeting of the Royal College of Physicians and Surgeons of Canada, Toronto, Ontario. January 29, 1977. 
TABLE I

Maximum Rise in Blood Cyanide and Serum Thiocyanate Following NitRoprusside INFUSION

\begin{tabular}{|c|c|c|c|c|c|}
\hline \multirow[b]{2}{*}{ Patient } & \multicolumn{3}{|c|}{ Nitroprusside infusion } & \multicolumn{2}{|c|}{ Measurements } \\
\hline & $\begin{array}{c}\text { Duration } \\
\text { (min) }\end{array}$ & $\begin{array}{c}\text { Dose } \\
(\mu \mathrm{g} / \mathrm{kg})\end{array}$ & $\begin{array}{c}\text { Rate } \\
(\mu \mathrm{g} / \mathrm{kg} / \mathrm{min})\end{array}$ & $\begin{array}{c}\text { Cyanide* } \\
\mu \mathrm{g} \%\end{array}$ & $\begin{array}{c}\text { Thiocyanate } \\
\mathrm{mg} \%\end{array}$ \\
\hline J.B. & 85 & 783 & 9.2 & 180 & 0.1 \\
\hline J.K. & 75 & 735 & 9.8 & 205 & 0.6 \\
\hline S.G. & $\tilde{5} 5$ & 495 & 9.0 & 110 & 0.2 \\
\hline S.T. & 35 & 340 & 9.2 & 90 & 0.0 \\
\hline R.R. & 86 & 146 & 1.7 & 53 & 0.5 \\
\hline A.L. & 15 & 84 & 1.4 & 40 & 0.4 \\
\hline M.B. & 15 & 60 & 4.0 & 35 & 0.6 \\
\hline F.D. & 20 & 60 & 2.0 & 20 & 0.0 \\
\hline H.H & 15 & 59 & 3.9 & 13 & 0.0 \\
\hline N.M. & 15 & 44 & 2.9 & 25 & 0.4 \\
\hline F.R. & 15 & 32 & 2.1 & 40 & 0.4 \\
\hline L.C. & 15 & 24 & 1.6 & 20 & 0.0 \\
\hline L.T. & 15 & 12 & 0.8 & 18 & 0.1 \\
\hline Mean & $35 . \overline{5}$ & $\underline{221}$ & $\underline{4.4}$ & 65.2 & 0.19 \\
\hline SE & & & & 17.5 & 0.09 \\
\hline $\mathrm{t}$ & & & & 3.7 & 2.11 \\
\hline $\mathrm{p}$ & & & & $<0.01$ & $<0.1$ \\
\hline
\end{tabular}

*The preinfusion cyanide was $2.7 \pm 1.4$ (mean $\pm \mathrm{SE}$ )

tThe preinfusion thiocyanate was $0.40 \pm 0.09$ (mean $\pm S E$ ).

supplement was given when necessary to maintain stable anaesthesia. The patients were ventilated at $0.1 \mathrm{l} / \mathrm{kg} / \mathrm{min}$ with a semiclosed circuit with fresh gas flow of $4.5 \mathrm{l} / \mathrm{min}$. The electrocardiogram and the arterial pressure, measured from an indwelling radial artery cannula, were monitored continuously. Urine output was monitored through an indwelling catheter. Mannitol 20 per cent 300 to $500 \mathrm{ml}$ was given routinely at the start of the anaesthetic to diminish brain volume. Fluid and electrolytes were given to maintain fluid balance. Blood loss during the operation was estimated by assessment of swabs and suction bottle. Four patients received a replacement transfusion of $500 \mathrm{ml}$ whole blood during the operation but none was administered in the post-operative period.

When hypotension was required for the surgical procedure, sodium nitroprusside $100 \mu \mathrm{g} / \mathrm{ml}$ in 5 per cent glucose in water was administered at a rate sufficient to lower the mean blood pressure to $50 \mathrm{~mm} \mathrm{Hg}$. To check for sensitivity to sodium nitroprusside, a small dose of the drug $(<1 \mathrm{mg})$ was given prior to initiating the infusion, which was administered from a $100 \mathrm{ml}$ chamber through a microdrip.

None of the patients studied experienced persistent hypotension, electrocardiographic changes, excessive blood or fluid losses or hypoxaemia. The mean duration of the operative procedure for the patients receiving nitroprusside was 4 hours 55 minutes. For the control craniotomy group it was 3 hours 15 minutes.

Arterial blood samples were withdrawn prior to the infusion of nitroprusside and every half-hour thereafter until four hours following the cessation of the infusion. Blood samples for $\mathrm{pH}, \mathrm{PO}_{2}, \mathrm{PCO}_{2}, \mathrm{ATP}$, lactate and pyruvate were 
collected in heparinized syringes, corked, and kept on ice until perchloric acid precipitates were made. Following centrifugation, the perchloric acid supernates were frozen until lactate, pyruvate and ATP were measured. Aliquots of heparinized blood were frozen for cyanide determinations. Serum samples were prepared and frozen for thiocyanate determinations. Cyanide was measured by the method of Shanahan. ${ }^{6}$ Thiocyanate was determined according to the method of Bowler as described by Varley. ${ }^{7}$ Pyruvate and lactate were determined by methods based on the enzymatic conversion of lactate to pyruvate with measurement of the change in absorbance at $340 \mathrm{~nm}$. Pyruvate was determined manually using a Boehringer Mannheim UV kit. Lactate was determined on the Dupont ACA. Blood ATP was measured using Sigma Kit 366-UV and a Unicam SP 1800 spectrophotometer. In this method the reaction of 3-phosphoglycerate and ATP is coupled with a dephosphorylation reaction catalyzed by glyceraldehyde phosphate dehydrogenase. A measure of the amount of ATP originally present is obtained by measuring the decrease in absorbance at $340 \mathrm{~nm}$ that results when $\mathrm{NADH}$ is oxidized to NAD. $\mathrm{pH}, \mathrm{Po}_{2}$ and $\mathrm{PcO}_{2}$ were measured using a Corning Model 165 $\mathrm{pH}$ Blood Gas Analyzer. Correlation coefficients were calculated by the standard method. The Student's paired t-test was used to test the significance of observed differences.

\section{Results}

Cyanide was detected in blood samples from all patients receiving sodium nitroprusside. The mean maximum rise in blood cyanide following the infusions was $65.2 \pm 17.5( \pm \mathrm{SE}) \mu \mathrm{g}$ per cent. In 3 of 13 nitroprusside treated and in 3 of 5 controls, cyanide ( $<10 \mu \mathrm{g}$ per cent) was detected before infusion. The individual maximum increases in blood cyanide and serum thiocyanate following sodium nitroprusside along with the infusion particulars are shown in Table I. The mean infusion dose was $221 \mu \mathrm{g} / \mathrm{kg}$ given over 36 minutes for a mean infusion rate of $4.4 \mu \mathrm{g} / \mathrm{kg} / \mathrm{min}$. The infusion commenced an average of 130 minutes after anaesthetic induction. The highest blood cyanide detected was $205 \mu \mathrm{g}$ per cent. With this number of patients the small rise in thiocyanate did not reach statistical significance. No changes in blood cyanide or serum thiocyanate were observed in the control patients.

The cyanide level peaked within 45 minutes after the nitroprusside was stopped except in patient J.B. who received the longest infusion. In that case the cyanide peaked while the nitroprusside was being given. In Figure 1 the mean $\pm \mathrm{SE}$ blood cyanide values obtained prior to, during, and following the nitroprusside infusion are plotted against time. This illustrates that the blood cyanide had returned to baseline values within five hours. In Figure 2 peak blood cyanide is plotted against total nitroprusside dose. A positive correlation is evident $(r=0.96)$. The correlation with the infusion rate was slightly less $(r=0.86)$.

Blood gases and acid base status were monitored during this study. The $\mathrm{Po}_{2}$ remained above $90 \mathrm{~mm} \mathrm{Hg}$ in all patients during and after the operation. The mean Pco. during the operation was $28 \mathrm{~mm} \mathrm{Hg}$ (range 20-33). During this time the patients had a mild elevation of blood $\mathrm{pH}$ (mean $\mathrm{pH}=7.491$ ). The mean intra-operative lactate level was $1.5 \mathrm{meq} / \mathrm{l}$. Similar values were found in the control 


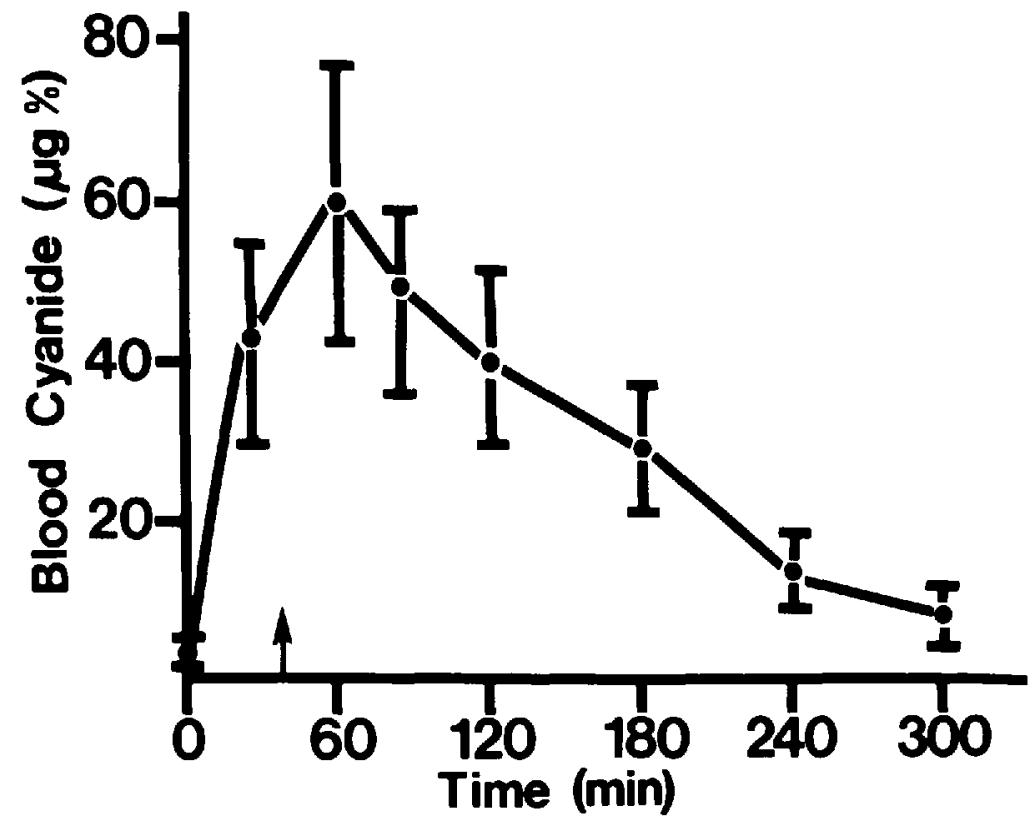

Frgune 1. Change in blood cyanide following initiation of nitroprusside infusion. Cyanide concentrations are presented as the mean $\pm S E(n=13)$. The end of the infusion period is indicated by the arrow.

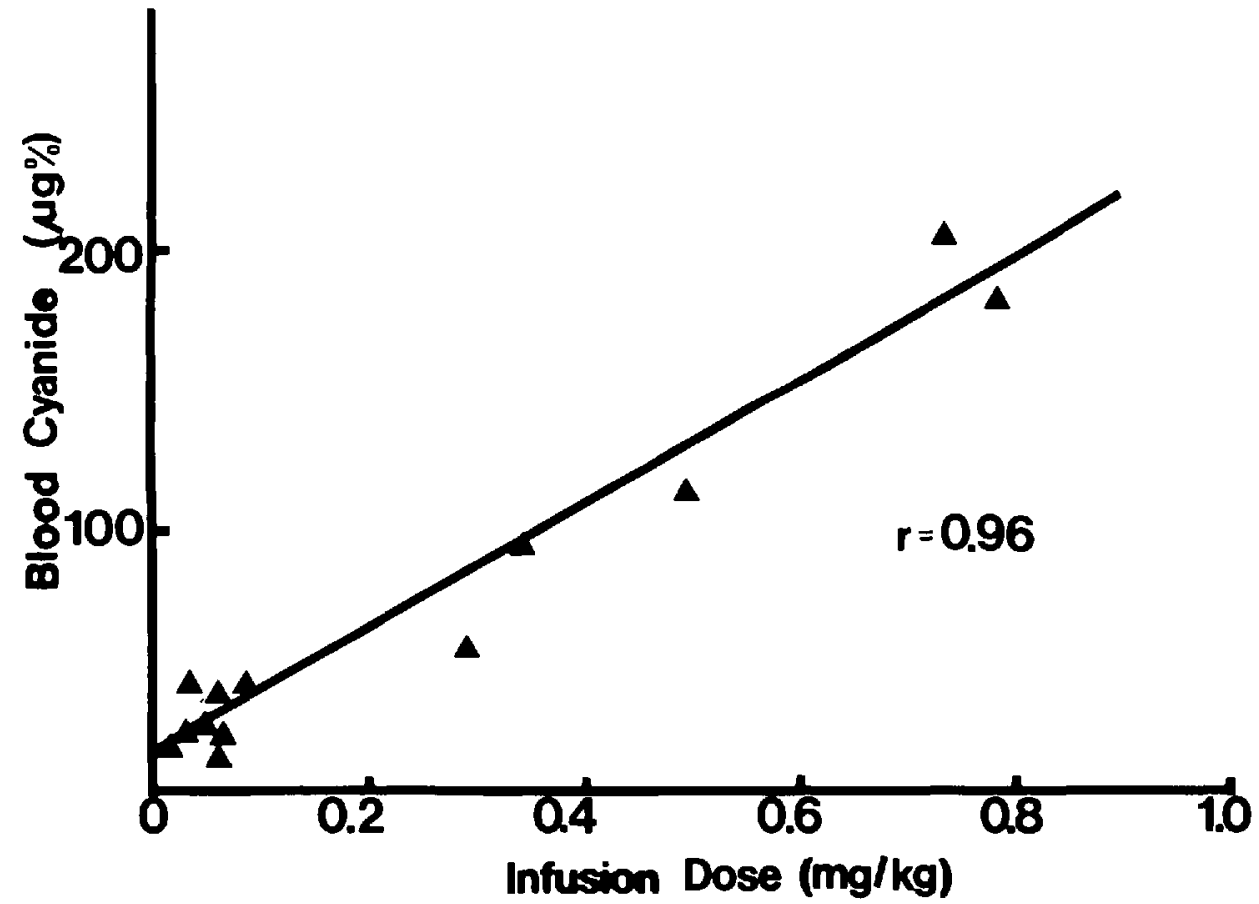

Figure 2. Relationship of peak blood cyanide to infusion dose. 


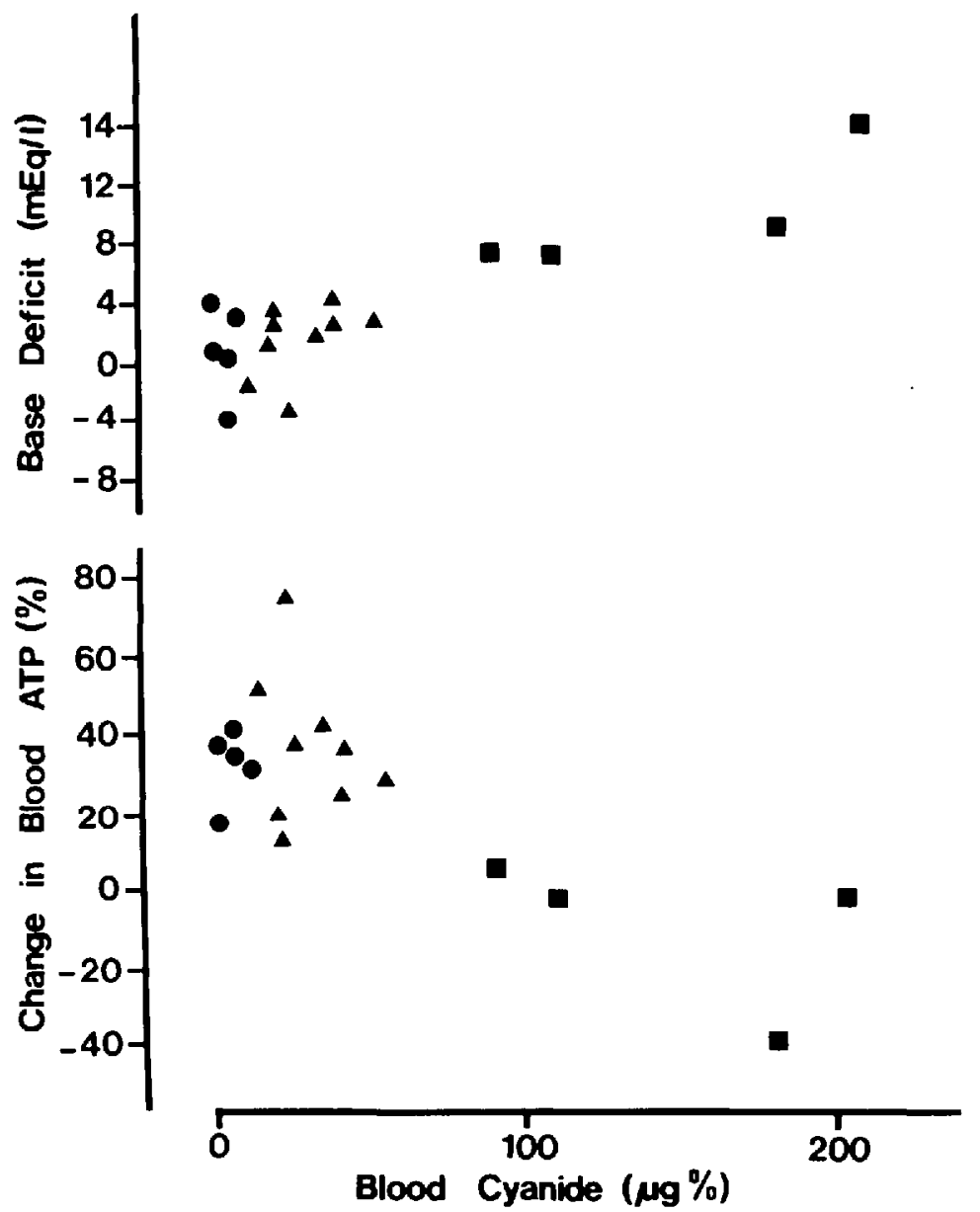

Figure 3. (upper panel) Maximum base deficit and peak blood cyanide in control ( $\bullet$ ) and patients treated with low ( $\boldsymbol{\Delta})$ and high $(\boldsymbol{\square})$ dose nitroprusside.

(lower panel) Percentage change in blood ATP during craniotomy and peak blood cyanide

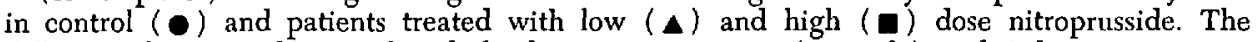
difference between the initial and the last intra-operative (controls) and $2 \mathrm{~h}$ post-operative (nitroprusside treated) whole blood ATP levels expressed as a percentage is presented in relation to the peak blood cyanide level.

group. Post-operatively the $\mathrm{pH}$ and $\mathrm{PcO}_{2}$ returned to normal but four nitroprussidetreated patients subsequently developed metabolic acidosis. Figure 3 (upper panel) depicts the relationship between the observed maximum base deficit and the peak blood cyanide in all cases $(\mathbf{r}=+0.89)$. The blood cyanide levels above $53 \mu \mathrm{g}$ per cent were associated with proportionately greater degrees of metabolic acidosis. The time relationship between the blood cyanide peak and the maximum base deficit in the four patients developing metabolic acidosis is shown in Figure 4. The maximum base deficit developed from 45 to 180 minutes following the peak cyanide level. Further biochemical data on these patients are presented in Table II. Only patient J.K. with the greatest metabolic acidosis exhibited all the changes to be found with tissue hypoxia. 


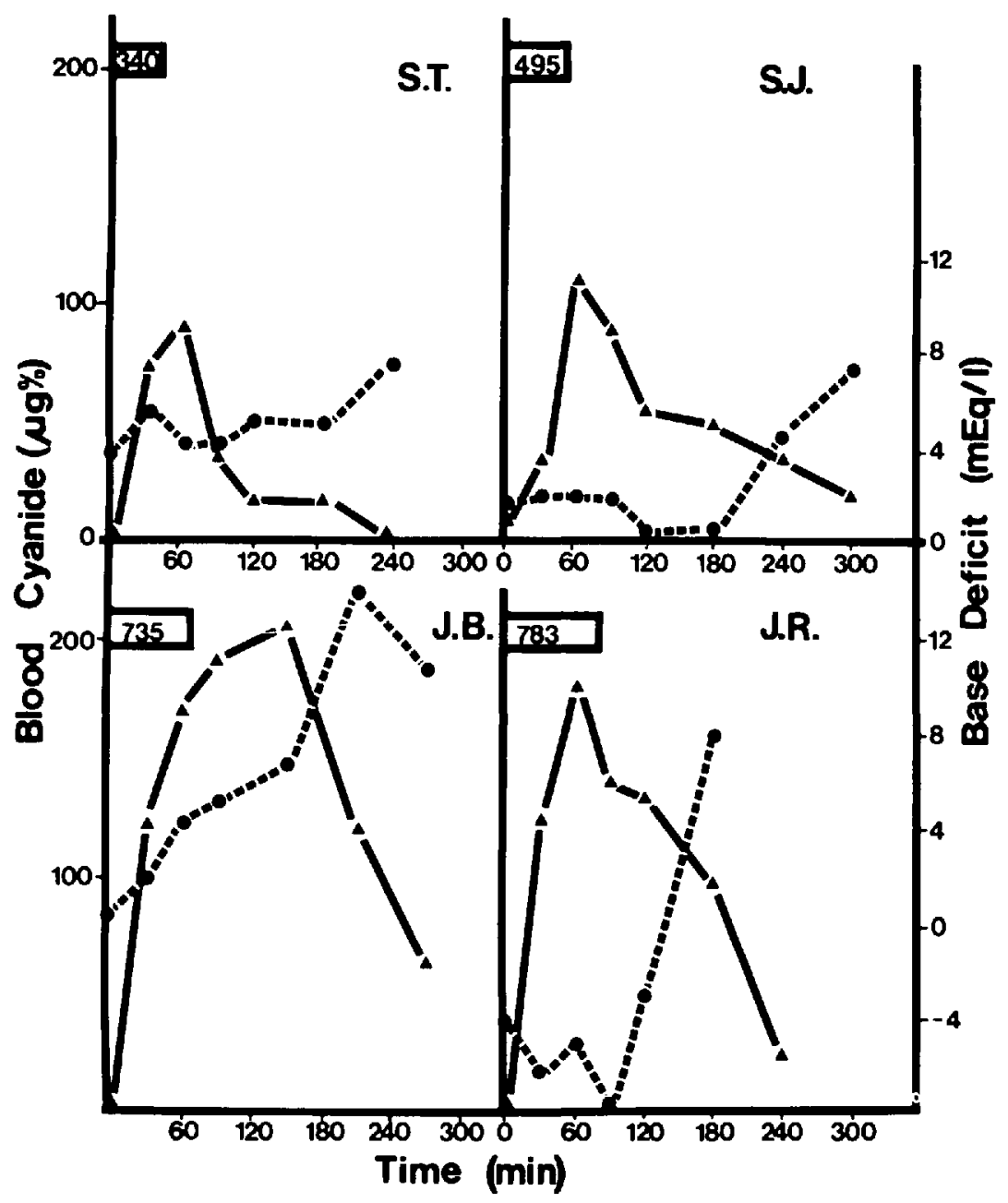

Ficune 4. Time relationship between peak blood cyanide and maximum base deficit. Blood cyanide $(-\boldsymbol{\Delta}-\boldsymbol{\Delta})$ and base deficit $(--\boldsymbol{0}--\boldsymbol{0})$ from the four patients developing significant base deficits are presented above. The infusion periods are represented by the rectangles and the infusion doses in $\mu \mathrm{g} / \mathrm{kg}$ are given by the numbers inside.

TABLE II

Biochemical Data at Time of Peak Base Deficit Following Nitroprusside

\begin{tabular}{lcccc}
\hline \hline \multicolumn{1}{c}{ Measurement } & \multicolumn{4}{c}{ Patients } \\
\cline { 2 - 5 } \cline { 3 - 5 } & S.T.* & S.G. & J.B. & J.K. \\
\hline Base deficit, meq/1 & 7.5 & 7.4 & 8.0 & 14.0 \\
pH, units & 7.362 & 7.229 & 7.200 & 7.178 \\
Pco, mm Hg & 28 & 49 & 44 & 38 \\
Blood lactate, meq/1 & 0.2 & 1.5 & 2.8 & 9.4 \\
Anion gap, meq/1 & 13 & 8 & 11 & 23 \\
Lactate/pyruvate ratio & 3 & 12 & 19 & 23 \\
\hline
\end{tabular}

*Patient still on assisted ventilation at time of this sampling. 
In Figure 3 (lower panel) the percentage change in blood ATP following the surgical procedures studied is presented. The ATP rose in the control group and in the nitroprusside treated patients except where high blood cyanide levels developed, then the ATP fell. A significant correlation between these measurements was not found in all patients studied.

\section{Discussion}

In this study, blood cyanide rose and serum thiocyanate was unchanged following intravenous administration of sodium nitroprusside. Smith and Kruszyna ${ }^{8}$ have shown that nitroprusside is converted to cyanide through a chemical reaction with haemoglobin. Four free cyanide ions and one molecule of methaemoglobin are formed for every nitroprusside molecule reacting. The cyanide ions diffuse out of the red cell and are ultimately metabolized in the liver and kidney to thiocyanate, which is slowly excreted in the urine. ${ }^{9}$ The extent to which cyanide becomes tissue bound is unknown. The unchanged thiocyanate level in this study is not unexpected as the nitroprusside administered is measured in $\mu \mathrm{g}$ quantities and the preinfusion serum thiocyanate in $\mathrm{mg}$.

We found that peak cyanide values occurred within 45 minutes following the nitroprusside infusions. In a previous study of dogs receiving 60 minute infusions, peak levels were reached by the end of the infusion. ${ }^{10}$ Vesey, et al., have found in humans that peak cyanide levels had occurred prior to one hour post-infusion. ${ }^{5}$ These results are in accord with current knowledge of nitroprusside pharmacology. In guinea pigs, signs of cyanide poisoning are observed five minutes after sodium cyanide is given, but are delayed 45 to 60 minutes after an equipotent dose of sodium nitroprusside. ${ }^{12}$ In vitro, the conversion of the total red cell haemoglobin to cyanmethaemoglobin takes one hour at $37^{\circ} \mathrm{C} .^{8}$

The peak blood cyanide level was closely related to the total nitroprusside administered in this study. This relationship was recently observed in patients receiving nitroprusside during major orthopaedic surgery. ${ }^{5}$ In that study, the mean cyanide level, infusion period and dose were approximately twice as great as in ours. A comparable relationship between blood cyanide and nitroprusside dose is apparent in Michenfelder's studies with dogs, where both were five times greater than in our study. In both human studies, the blood cyanide correlated better with the total nitroprusside dose than with the infusion rate. If this is considered along with Baine and Gettler's ${ }^{11}$ finding that in cyanide poisoning death is determined by total dose absorbed and the rate of absorption only affects its timing, then in the short-term use of nitroprusside the total dose administered, not the infusion rate, should be regarded as the prime determinant of toxicity.

The wide dose range used in this study reflects both the varying periods of hypotension required for surgery as well as major differences in the sensitivity of the patients to the drug (Table I). Davies, et al. ${ }^{13}$ have described three different response patterns to nitroprusside, emphasizing the significance of both resistance and tachyphylaxis. We were unable to correlate sensitivity to the drug with age, sex, or smoking habits in our patients, all of whom had normal renal and liver function. Tachyphylaxis with nitroprusside may be a consequence of a pressor 
effect of cyanide on the chemoreceptors, ${ }^{14}$ possibly augmented by acidosis. It may not have occurred in this study because the cyanide levels attained during the infusion were low.

The higher blood cyanide levels detected in this study are in the range of reported minimum lethal blood cyanide values. ${ }^{5}$ Vessey, et al. ${ }^{5}$ have pointed out that red cell cyanide is higher when it is derived from nitroprusside metabolism rather than cyanide absorption, so that similar whole blood cyanide levels may not be associated with comparable toxicity in these two situations. In their study higher cyanide levels than ours were recorded without any reported morbidity; however, none of the possible metabolic indices of cyanide poisoning were measured. McDowall, et al. ${ }^{15}$ found severe metabolic acidaemia in baboons that failed to recover from high doses of nitroprusside but did not report any cyanide levels. Michenfelder ${ }^{10,16}$ found metabolic derangements compatible with cyanide intoxication in dogs infused with sodium nitroprusside $<1 \mathrm{mg} / \mathrm{kg}$ and more marked changes when this dosage was exceeded.

The occurrence of unexplained metabolic acidosis in our patients with higher blood cyanide levels is suggestive of cyanide toxicity. The base deficit is affected by many factors such as hypoxia, hyperventilation, infusion of intravenous agents, drugs, altered renal and hepatic function. We attempted to control these variables by standardizing the clinical procedures used. Review of our data did not reveal an association between length of operation and subsequent acidosis. Patients in the control and low nitroprusside dose groups developed minor intra-operative increases in lactate which resolved in the immediate post-operative period. There was no correlation between lactate levels and mean intra-operative Pco.2 levels or the degree of hypotension. In the four patients receiving more than $0.3 \mathrm{mg} / \mathrm{kg}$ nitroprusside, a significant base deficit developed which resulted in moderate acidaemia. In patients J.K. and J.B. hyperlactaemia and elevation of the lactate/pyruvate ratio compatible with cellular hypoxia were detected. The contribution of $\beta$-hydroxybutyric acid to the picture cannot be assessed, as it was not measured.

Whole blood ATP formation was depressed proportional to the presence of high blood cyanide levels. Blood ATP was measured as an indicator of aerobic metabolism, although the validity of this is uncertain considering the contribution of red cells to blood ATP. Red cell organic phosphates normally rise during hyperventilation and cyanide may interfere with this. The effect may be indirect; i.e., the stimulatory effect of respiratory alkalosis ${ }^{17}$ may be blocked by the development of metabolic acidosis.

We conclude that some degree of cellular hypoxia due to cyanide accumulation results from the rapid administration of sodium nitroprusside in the $0.3-1.0 \mathrm{mg} / \mathrm{kg}$ dose range. This alone may not cause major problems, but it may well aggravate adverse conditions as this drug is commonly used in intracranial surgery, cardiogenic shock and hypertensive crises, where cerebro-vascular spasm, atheroma, diminished blood pressure and cardiac output commonly occur. To distinguish between tissue hypoxia secondary to hypoperfusion and that due to cellular toxins is difficult, so that when this occurs it can easily but wrongly be 
attributed to the existing primary pathology. Further, the delayed appearance of acidosis may be exacerbated in the post-operative period by a rising $\mathrm{Pco}_{2}$. This was noticed in our patients J.K., J.B. and S.G. when ventilation support was withdrawn. Dangerous acidaemia may ensue and close monitoring of the $\mathrm{pH}$ should continue for several hours after the administration of sodium nitroprusside. Specific precautions may be taken to minimize the dangers of sodium nitroprusside infusion; ${ }^{18}$ however, we feel that the recommended dose of this agent should be further revised downward to $<0.5 \mathrm{mg} / \mathrm{kg}$.

\section{SUMMARY}

Several recently reported deaths following the use of sodium nitroprusside have been attributed to the accumulation of the nitroprusside metabolite, cyanide. In this study, brief nitroprusside infusions (mean $=36$ minutes) were administered in currently recommended doses during intracranial surgery. The peak blood cyanide following the infusions was $65.2 \pm 17.5 \mu$ g per cent (mean \pm SE) $(n=13)$. It occurred within 45 minutes after infusion. The highest cyanide level detected was $205 \mu \mathrm{g}$ per cent, which is within the range of reported lethal blood cyanide levels. Metabolic acidosis developed in the four patients with the highest blood cyanide levels (range 90-205 $\mu \mathrm{g}$ per cent). This occurred between 45 and 180 minutes following the cyanide peak. Blood ATP levels were depressed in the same patients. These findings are indicative of disturbed aerobic metabolism. We conclude that there is evidence of cyanide toxicity when nitroprusside is infused into patients using currently recommended doses. We recommend that for short infusions the dose of sodium nitroprusside should not exceed $0.5 \mathrm{mg} / \mathrm{kg}$.

\section{RÉSUMÉ}

Plusieurs décès rapportés récemment, consécutivement à l'usage de nitroprussiate de soude, ont été attribués à l'accumulation de cyanure, dérivé métabolique du nitroprussiate. Au cours de cette étude, des infusions de nitroprussiate d'une durée moyenne de 36 minutes ont été administrées lors de chirurgie intracrânienne, au dosage pormalement recommendé. La quantité maximale de cyanure sérique, obtenu endéans les 45 minutes qui ont suivi l'infusion, était de $65.2 \pm 17.5$ $\mu$ g pour cent (moyenne \pm erreur std, $n=13$ ). Le niveau de plus élevé de cyanure était de $205 \mu \mathrm{g}$ pour cent, quantité comprise dans l'écart des niveaux de cyanure sérique considérés comme mortels. Une acidose métabolique s'est développée chez les quatre patients qui ont indiqué les niveaux de cyanure les plus élevés (de 90 à $205 \mu \mathrm{g}$ pour cent). Cette acidose s'est produite entre 45 et 180 minutes après le niveau maximal. Les niveaux d'ATP sérique étaient diminués chez ces mêmes patients. Ces résultats indiquent un dérangement du métabolisme aérobique. En conclusion, un état de toxicité dû au cyanure se développe lorsque les patients sont soumis à une infusion de nitroprussiate aux doses normalement recommendées. Nous conseillons, pour le cas d'infusions brèves, que la dose de nitroprussiate n'excède pas $0.5 \mathrm{mg}$ par kg. 


\section{ACKNOWLEDGEMENTS}

We wish to thank Drs. Ian Hart, Jean Himms-Hagen, and Eli Rabin for their advice in the preparation of this manuscript. A special thanks to Marni Linton for the infinite patience she exhibited during that same period.

\section{REFERENCES}

1. Editorial. Sodium nitroprusside in anaesthesia. British Medical Journal 2: 524-525 (1975).

2. Merrifield, A.Y. \& Blundell, M.D. Toxicity of sodium nitroprusside. British Journal of Anaesthesia 46: 324 (1974).

3. Davies, D.W., Kadar, D., Steward, D.J., et al. A sudden death associated with the use of sodium nitroprusside for induction of hypotension during anaesthesia. The Canadian Anaesthetists' Society Journal 22: 547-551 (1975).

4. Posner, M.A., Rodkey, F.L., \& Tobey, R.E. Nitroprusside-induced cyanide poisoning: antidotal effect of hydroxocobalamin. Anaesthesiology 44: 330-335 (1976).

5. Vesey, C.J., Cole, P.V., \& Simpson, P.J, Cyanide and thiocyanate concentrations following sodium nitroprusside infusion in man. British Journal of Anaesthesia 48: 651-660 (1976).

6. Shanahan, R. The determination of sub-microgram quantities of cyanide in biological materials. Journal of Forensic Science Society 18: 25-30 (1973).

7. VARLEy, H. Determination of serum thiocyanates. Practical clinical biochemistry, 4th ed. London: William Heinemann Medical Books Ltd. (1967).

8. SMITH, R.P. \& KRUSzYNA, H. Nitroprusside produces cyanide poisoning via a reaction with hemoglobin. Journal of Pharmacology and Experimental Therapeutics 191: 557-563 (1974).

9. Tinken, J.H. \& Michenfelder, J.D. Sodium nitroprusside: pharmacology, toxicology and therapeutics. Anaesthesiology 45: 340-352 (1976).

10. Michenfelder, J.D. Cyanide release of sodium nitroprusside in dogs. Anaesthesiology 46: 196-201 (1977).

11. Mahaffex, L.W. Toxicity of sodium nitroprusside for guinea pigs. Australian Chemical Institution Journal and Proceedings 9: 93-94 (1942).

12. Getrler, A.O. \& Baine, J.O. The toxicology of cyanide. American Journal of the Medical Sciences 195: 182-198 (1938).

13. Davies, D.W., Greiss, L., Kadar, D., \& Sreward, D.J. Sodium nitroprusside in children. Observations on metabolism during normal and abnormal responses. The Canadian Anaesthetists' Society Journal 22: 553-560 (1975).

14. Krasney, J.A. Cardiovascular responses to cyanide in awake sinoaortic denervated dogs. American Journal of Physiology 220: 1361-1366 (1971).

15. McDowall, D.G., Keaney, N.P., Turner, J.M. et al. The toxicity of sodium nitroprusside. British Journal of Anaesthesia 46: 327-332 (1974).

16. Michenfelder, J.D. \& Theys, R.A. Canine systemic and cerebral effects of hypotension induced by haemorrhage, trimethaphan, halothane or nitroprusside. Anaesthesiology 46: 188-195 (1977).

17. Miller, M.E., Rorth, M., Parving, H.H., et al. $\mathrm{pH}$ effect on erythropoietin response to hypoxia. New England Journal of Medicine 288: 706-710 (1973).

18. Greiss, L., Tremblay, N.A.G., \& Davies, D.W. The toxicity of sodiun nitroprusside. The Canadian Anaesthestists' Society Journal 22: 480-485 (1976). 